\title{
Occurrence of Giardia duodenalis assemblages in farmed long-tailed chinchillas Chinchilla lanigera (Rodentia) from Romania
}

\author{
Călin Mircea Gherman, Zsuzsa Kalmár*, Adriana Györke and Viorica Mircean
}

\begin{abstract}
Background: Giardia duodenalis is a parasitic protist that infects a large number of species, being localized in the small intestine. Two of the eight recognized assemblages have zoonotic potential, but studies regarding their distribution in less important pet or farm species are scarce. Of these species, the long-tailed chinchilla is a host for Giardia spp., although data on the spread of infection and assemblages involved are confined. The present work aimed to determine the prevalence of Giardia infection and assemblage identification in farmed chinchillas in Romania. A total of 341 fecal samples were collected from 5 farms and microscopically examined using flotation test based on saturated sodium chloride solution. DNA from all positive samples was extracted and identified by PCR targeting the gdh gene.
\end{abstract}

Results: The overall prevalence of Giardia infection was 55.7\% (190/341); there was no statistically significant difference $(P=0.25)$ in prevalence between young animals (58.8\%) and adults (52.6\%). Assemblages B (151/190), D $(33 / 190)$ and $E(6 / 190)$ were identified. Among assemblage B, sub-assemblages BIII (6/151) and BIV (145/151) were determined.

Conclusions: This study demonstrates that Giardia spp. infection is highly prevalent in farmed chinchillas from Romania, and the sub-assemblages identified are potentially zoonotic.

Keywords: Farmed long-tailed chinchilla, Chinchilla lanigera, Giardia duodenalis, Prevalence, Assemblages, Romania

\section{Background}

The genus Giardia contains six species of aerotolerant anaerobic enteric protozoan parasites isolated from mammals, birds and amphibians [1-4]. Of all these species, three infect mammals, Giardia muris and G. microti in rodents and $G$. duodenalis commonly in a broad range of mammalian hosts [5]. Within G. duodenalis, eight species assemblages, or genotypes, are currently recognized, named from A to G. The hosts of assemblages $\mathrm{A}$ and $\mathrm{B}$ of $\mathrm{G}$. duodenalis are the humans and other primates, livestock, domestic carnivores and wild mammals; $\mathrm{C}$ and $\mathrm{D}$ infect canids, $\mathrm{E}$ is common in

\footnotetext{
*Correspondence: zsuzsa.kalmar@usamvcluj.ro

Parasitology and Parasitic Diseases Department Cluj-Napoca, University of Agricultural Sciences and Veterinary Medicine Cluj-Napoca, Faculty of Veterinary Medicine, Cluj-Napoca, Romania

hoofed livestock, F is typical for cats, G infects rodents and $\mathrm{H}$ was isolated from marine mammals [6]. The most important are zoonotic assemblages $\mathrm{A}$ and $\mathrm{B}$, within each of them being isolated by protein polymorphisms or allozyme electrophoresis four sub-assemblages (AI, AII, AIII, AIV and BI, BII, BIII, BIV, respectively) [7, 8].

In Romania, limited data exist regarding the prevalence of Giardia infection in animals. Recently, the presence of G. duodenalis was reported in domestic carnivores; the overall prevalence was $8.5 \%$ in dogs and $27.9 \%$ in cats $[9,10]$. Furthermore, assemblages A (AII), B, C (10/60; $16.7 \%), D(42 / 60 ; 70.0 \%)$, and $E(7 / 60 ; 11.7 \%)$ have been identified in domestic and wild animals (dogs, cats, foxes, deer, wolves, raccoon dogs and muskrats) [11-13]. Consequently, the study of Giardia spp. infection in Romania is a field of high importance. 
The long-tailed chinchillas (C. lanigera) are mountainous and crepuscular animals native to South America. Extensively hunted for their fur during the 19th century the species is now almost extinct in the wild, several colonies being identified only in Chile [14]. Due to their complex social behavior and attractive aspect, chinchillas became increasingly popular as pets across the world. At the same time, because of the softest, longest and finest furs among wild animals, the species became of interest for animal breeders. Farming of chinchilla dates back to 1923, when M. F. Chapman began to raise chinchillas in captivity, being the inception of what has become an industry [15]. Intensive farming exposed chinchillas to different pathogens, which are probably less common in the wild animals. Of these, water-borne parasitic diseases, particularly giardiasis, may cause clinical and sanitary problems and lead to production and economic losses [16]. Currently, there are about 75 chinchilla farms in Romania, with a production of 12,500 animals exported per year. It manifests also an increasing trend of chinchillas' farming, whose debut in Romania dates back about 10 years ago (http://agfcicr.ro/). Due to the increasing number of farmed chinchillas in Romania, and the lack of information on the occurrence and zoonotic potential of G. duodenalis in these animals, the present study aimed to investigate the prevalence of the infection and preliminary genotyping of the isolates in Romanian chinchilla farms.

\section{Methods}

\section{Animals and collection sites}

Five farms with an overall stock of 5500 animals were involved in the study. Of these 2200 were breeding animals and the rest were kits and young of different ages. The following abbreviations were used for the farms studied: BM, RG, SB, SM and LU. All farms use the intensive growth closed system, but farms BM and RG also buy animals from small farmers who grow chinchillas in polyspecific farms exposed to contact with other species. A total of 341 fecal samples were collected, representing $6.2 \%$ of the stock. Of these, 171 samples were from chinchilla mothers and 170 from young animals (Table 1).

\section{Sample processing}

Each fecal sample was individually examined by flotation technique using saturated sodium chloride solution (specific gravity 1.28) [17], followed by microscopic examination (light microscopy, magnification: 10×, 20×, 40×) for the identification of Giardia cysts. Briefly, $0.5 \mathrm{~g}$ of feces/sample was homogenized with $10 \mathrm{ml}$ of distilled water, filtered and centrifuged at $3000 \times g$ for $10 \mathrm{~min}$. The supernatant was discarded, and the sediment containing Giardia cysts was transferred to an Eppendorf tube and used for DNA extraction.

\section{DNA extraction and PCR analysis}

DNA extraction was performed from Giardia-positive samples, confirmed by microscopic examination, using Isolate Fecal DNA kit (Bioline, London, UK). To increase the specificity of DNA amplification, a semi-nested PCR reaction was performed targeting the glutamate dehydrogenase $(g d h)$ gene in a T100 Thermal Cycler (Bio-Rad, Hercules, USA) $[18,19]$. The PCR reaction mix contained $2 \times$ Red PCR Master mix (Rovalab, Teltow, Germany), 12 pmol of primers, $1 \mu \mathrm{l}$ of genomic DNA; the reaction profile consisted of 1 cycle of initial denaturation at $95{ }^{\circ} \mathrm{C}$ for $5 \mathrm{~min}$, followed by 40 cycles of $30 \mathrm{~s}$ each at $94{ }^{\circ} \mathrm{C}$, annealing at $50{ }^{\circ} \mathrm{C}$ for $30 \mathrm{~s}$ for the primary reaction and $60{ }^{\circ} \mathrm{C}$ for secondary reaction, extension at $72{ }^{\circ} \mathrm{C}$ for $1 \mathrm{~min}$ and final extension at $72{ }^{\circ} \mathrm{C}$ for $5 \mathrm{~min}$. Agarose gel (1.5\%) electrophoresis stained with SYBR Safe DNA gel stain (Invitrogen, Carlsbad, USA) was performed for the visualization of PCR products.

\section{RFLP}

For discrimination of all assemblages of G. duodenalis, RFLP analysis was performed using Rsa I and NlaIV (Biolabs, New England, US) restriction enzymes [18]. The amplified fragments were digested in a total volume of $50 \mu \mathrm{l}$, as recommended by the manufacturer's instructions, $5 \mathrm{~min}$ at $37{ }^{\circ} \mathrm{C}$ for RsaI, $1 \mathrm{~h}$ for NlaIV, and the reactions were stopped by $20 \mathrm{~min}$ of incubation at $60{ }^{\circ} \mathrm{C}$. The digested products were visualized by electrophoresis on $3 \%$ agarose gel.

Table 1 Prevalence of G. duodenalis in fecal samples collected from long-tailed chinchillas in farms in Romania

\begin{tabular}{|c|c|c|c|c|c|c|c|c|}
\hline \multirow{2}{*}{$\begin{array}{l}\text { Farm } \\
\text { code }\end{array}$} & \multicolumn{2}{|l|}{ Total } & \multicolumn{2}{|c|}{ Chinchilla mothers } & \multicolumn{2}{|c|}{ Kits/young } & \multicolumn{2}{|l|}{ Comparison } \\
\hline & $F$ & $\begin{array}{l}\text { Prevalence (\%) } \\
(95 \% \mathrm{Cl})\end{array}$ & $\mathrm{F}$ & $\begin{array}{l}\text { Prevalence } \\
(\%)(95 \% \mathrm{Cl})\end{array}$ & $\mathrm{F}$ & $\begin{array}{l}\text { Prevalence } \\
(\%)(95 \% \mathrm{Cl})\end{array}$ & Chi-square & $P$-value \\
\hline$\overline{B M}$ & $49 / 80$ & $61.3(49.7-71.9)$ & $29 / 52$ & $55.8(41.3-69.5)$ & $20 / 28$ & $71.4(51.3-86.8)$ & 1.880 & 0.170 \\
\hline RG & $56 / 80$ & $70.0(58.7-79.7)$ & $24 / 28$ & 85.7 (67.3-96.0) & $32 / 52$ & $61.5(47.0-74.7)$ & 5.065 & 0.024 \\
\hline SB & $40 / 60$ & $66.7(53.3-78.3)$ & $18 / 30$ & $60.0(40.7-77.3)$ & $22 / 30$ & $73.3(54.1-87.7)$ & 1.200 & 0.273 \\
\hline SM & $19 / 60$ & $31.7(20.3-45.0)$ & $9 / 30$ & $30.0(14.7-49.4)$ & $10 / 30$ & $33.3(17.3-52.8)$ & 0.077 & 0.781 \\
\hline LU & $26 / 61$ & $42.6(30.0-55.9)$ & $10 / 31$ & $32.3(16.7-51.4)$ & $16 / 30$ & $53.3(34.3-71.7)$ & 2.769 & 0.096 \\
\hline Total & $190 / 341$ & $55.7(50.3-61.1)$ & $90 / 171$ & $52.6(44.9-60.3)$ & $100 / 170$ & $58.8(51.0-66.3)$ & 1.325 & 0.2497 \\
\hline
\end{tabular}




\section{DNA sequencing}

The PCR products were purified by using QIAquick PCR purification kit (Qiagen, Hilden, Germany) and sequenced at Macrogen Europe (Amsterdam). Nucleotide sequence data from this study were submitted to the GenBank database under the accession numbers MG432793-MG432795.

\section{Statistical analysis}

The frequency of Giardia-positive samples, their prevalence and 95\% confidence interval were calculated. The difference in prevalence between age groups and among farms was statistically analyzed by a Chi-square test. Statistical significance was set at a $P$-value of $\leq 0.05$. All statistical analyses were performed using EpiInfo software version 3.5.1. (Centers for Disease Control and Prevention: http://wwwn.cdc.gov/epiinfo/).

\section{Results}

The occurrence of Giardia spp.

Giardia cysts were identified in 190 of 341 (55.7\%, 95\% CI: 50.3-61.0) fecal samples by microscopic examination. All 190 microscopically identified Giardia-positive samples were positive by PCR. General prevalence recorded the highest value in farm RG (56/80, 70\%, 95\% CI: 58.7-79.7\%) and the lowest in farm SM (19/60, 31.6, 95\% CI: $20.3-45.0 \%)\left(\chi^{2}=28.83, d f=4, P<0.001\right)$. The infection was somewhat more frequent in young animals (100/170, 58.8\%, 95\% CI: 51.0-66.3\%) compared to mother chinchillas $(90 / 171,52.6 \%$, 95\% CI: 44.9$60.3 \%)$ but the difference was not statistically significant $\left(\chi^{2}=1.09, d f=1, P=0.25\right)$ (Table 1 ).

\section{Giardia spp. assemblages}

In total, three Giardia assemblages (B, D and E) were found in the chinchilla farms studied. Assemblage B was the most prevalent $(151 / 190,79.5 \%)$, followed by D (33/ $190,17.4 \%)$ and $E(6 / 190,3.1 \%)$. The identified subassemblages were BIV (145/190, 76.3\%) and BIII (6/190; 3.1\%) (Table 2).

Sequence analysis of fecal samples confirmed the infection with $G$. duodenalis sub-assemblages BIII, BIV, D and E (Table 2). Assemblages B (MG432795) and D (MG432793) were common in all farms in the study, in both age categories, and Assemblage E (MG432794) was identified only in farms BM and RG. No mixed assemblage infections were detected in animals in this study.

\section{Discussion}

The study of intestinal parasites in the long-tailed chinchilla is an important field of interest due to a permanent contact of this pet or farmed animal with humans. Among parasitic diseases identified in this species, giardiasis seems to be the most significant, due to the zoonotic character and increased values of prevalence reported worldwide (Table 3).
Table 2 Assemblages of G. duodenalis identified by PCR-RFLP and sequencing targeting the $g d h$ gene in fecal samples of long-tailed chinchillas from farms in Romania

\begin{tabular}{|c|c|c|c|c|c|c|c|}
\hline \multirow[t]{2}{*}{ Farm } & \multirow[t]{2}{*}{ Age } & \multicolumn{2}{|c|}{ Assemblage (RFLP) } & \multicolumn{4}{|c|}{$\begin{array}{l}\text { Assemblage (sequencing) } \\
\text { (no. of samples) }\end{array}$} \\
\hline & & NlalV & Rsal & $\mathrm{BIII}$ & BIV & $\mathrm{D}$ & $E$ \\
\hline \multirow[t]{2}{*}{$\mathrm{BM}$} & CM & BIII/BIV/E/D & BIII; BIV & 3 & 20 & 4 & 2 \\
\hline & Y & BIII/BIV/D & BIV & & 16 & 4 & \\
\hline \multirow[t]{2}{*}{$\mathrm{RG}$} & CM & BIII/BIV/D/E & BIV & & 19 & 3 & 2 \\
\hline & Y & BIII/BIV/D/E & BIV & 1 & 22 & 7 & 2 \\
\hline \multirow[t]{2}{*}{ SB } & $\mathrm{CM}$ & BIII/BIV/D & BIV & & 15 & 3 & \\
\hline & Y & BIII/BIV/D & BIII; BIV & 2 & 17 & 3 & \\
\hline \multirow[t]{2}{*}{ SM } & CM & BIII/BIV/D & BIV & & 4 & 5 & \\
\hline & Y & BIII/BIV & BIV & & 10 & & \\
\hline \multirow[t]{2}{*}{ LU } & $\mathrm{CM}$ & BIII/BIV/D & BIV & & 8 & 2 & \\
\hline & Y & BIII/BIV/D & BIV & & 14 & 2 & \\
\hline Total & & & & 6 & 145 & 33 & 6 \\
\hline
\end{tabular}

Abbreviations: $C M$ chinchilla mothers, $Y$ young

Table 3 Reported prevalence of Giardia spp. infection in the long-tailed chinchilla

\begin{tabular}{|c|c|c|c|c|c|}
\hline Country & $\begin{array}{l}\text { Husbandry } \\
\text { system (pet/ } \\
\text { farmed/wild) }\end{array}$ & $\begin{array}{l}\text { Prevalence } \\
(\%)\end{array}$ & Frequency & $\begin{array}{l}\text { Detection } \\
\text { method }\end{array}$ & Reference \\
\hline Argentina & Farmed & 34.42 & $84 / 244$ & $\begin{array}{l}\text { Wet } \\
\text { mounts, } \\
\text { IFA }\end{array}$ & {$[46]$} \\
\hline Belgium & Pet & 66.3 & $53 / 80$ & SCF & [24] \\
\hline Brazil & Farmed & 8.0 & $20 / 250$ & ZCF & {$[47]$} \\
\hline Brazil & Farmed & 38.0 & $38 / 100$ & ZCF & {$[48]$} \\
\hline Brazil & Pet & 10.0 & $6 / 60$ & ZCF & [49] \\
\hline Brazil & Farmed & 31.37 & $80 / 255$ & ZCF & {$[28]$} \\
\hline Chile & Wild & Negative & na & & - \\
\hline China & Pet & 37.5 & $36 / 96$ & SF & {$[50]$} \\
\hline China & Pet & 27.1 & $38 / 140$ & PCR & {$[51]$} \\
\hline Europe & Pet & 61.4 & $326 / 531$ & ELISA & [31] \\
\hline Italy & Farmed & 39.4 & $41 / 104$ & DFA & [31] \\
\hline Portugal & Pet & $35.2-92.3$ & na & ZCF, SF & {$[52]$} \\
\hline Russia & Pet & 50.0 & $25 / 50$ & CFM & {$[53]$} \\
\hline Russia & Pet & Positive & na & ANF & [29] \\
\hline Peru & Wild & Negative & na & & - \\
\hline Romania & Farmed & 55.7 & 190/341 & $\mathrm{NaClF}$ & $\begin{array}{l}\text { Present } \\
\text { study }\end{array}$ \\
\hline
\end{tabular}

Abbreviations: ANF ammonium nitrate flotation, CFM combined flotation method, DFA direct fluorescent assay, ELISA enzyme-linked immunosorbent assay, IFA immunofluorescence assay, na not applicable, NaCIF sodium chloride flotation, SCF sucrose gradient centrifugation-flotation technique, SF sugar flotation (Sheather's sugar solution), ZCF zinc-sulfate centrifugation-flotation 
The prevalence revealed in the present study (55.7\%) is slightly increased compared to that reported in farmed chinchilla from other regions (8.0-38.0\% in Brazil, $34.4 \%$ in Argentina and $39.4 \%$ in Italy) but is comparable to those reported in pet animals (10.0-92.3\%).

The discrepancies of prevalence recorded in existing studies can be explained by the different diagnostic value of copromicroscopic methods used, determined by the technique, less than the density of supersaturated solutions [20]. Moreover, coproscopic techniques have a lower diagnostic value, the prevalence determined by other modern serological or molecular methods (ELISA, IFA, PCR) being 2.6-fold higher in dogs and 3.7-fold higher in cats [21]. As such, we consider that the prevalence of infection revealed in this study, although high, can be appreciated as undervalued.

Prevalence of Giardia infection is generally influenced by many factors, such as the sensitivity of the diagnostic method used, the peculiarities of the biological cycle of the parasite (the discontinuities of cysts removal), the host, the age of host, the growth system, and the hygiene conditions (water, food, bedding) [22]. A variety of factors favor the emergence and transmission of infection in chinchilla populations. These risk factors may differ among pet and farmed chinchilla. Regarding pet chinchilla, participation in shows and contact with other pet animals, such as dogs, cats or other rodents, are significant [23, 24]. In farmed chinchillas, the age of animals, stress, poor husbandry system associated with low quality of water source, overcrowding and close contact with feces seems to act as predisposing factors. Juvenile chinchillas are more sensitive to acquire the infection [25]. Intensive rearing in plastic or metal cages, with fecal accumulation underneath and vulnerability of the drinking-waterprocessing system, favor the contact between animals and cysts of Giardia spp. [26, 27]. Captivity associated with specific stress emphasizes the sensitivity of chinchilla to $G$. duodenalis infection, an aspect demonstrated by the absence of Giardia spp. infection in wild animals [28, 29].

Chinchillas harbor various assemblages (A, B, C, D and $\mathrm{E}$ ) of $\mathrm{G}$. duodenalis, representing a potential zoonotic risk (Table 4). Assemblage B is the most common, being identified in almost all reported studies, except for an axenic isolate of G. duodenalis from Germany [30], in which assemblage A was identified. In our research, RFLP analysis of G. duodenalis-positive samples revealed a high occurrence of assemblage B isolates grouped into sub-assemblages BIII and BIV, representing the main assemblages involved in chinchilla's infection. In the present study, no mixed assemblage infections were detected, similar to previous studies [16, 31]. However, our data do differ from those reported in Belgium and Germany, which showed the presence of mixed assemblage A, B, C and E infections in chinchillas [24, 32].
Table 4 Assemblages of G. duodenalis identified in the long-tailed chinchillas

\begin{tabular}{|c|c|c|c|}
\hline \multirow[t]{2}{*}{ Country } & \multicolumn{2}{|c|}{$\begin{array}{l}\text { Type of animal (pet/farmed)/ } \\
\text { assemblage }\end{array}$} & \multirow[t]{2}{*}{ Reference } \\
\hline & Pet & Farmed & \\
\hline Austria & B & - & {$[32]$} \\
\hline Belgium & $\mathrm{A}, \mathrm{Al}, \mathrm{All}, \mathrm{B}, \mathrm{BIV}, \mathrm{C}, \mathrm{E}$ & - & [24] \\
\hline Brazil & B & - & [16] \\
\hline Brazil & BIV & - & {$[54]$} \\
\hline China & Al, All, BIV, BIV-1, BIV-2 & - & [51] \\
\hline Croatia & B & - & {$[55]$} \\
\hline Czech Republic & B & - & {$[56]$} \\
\hline Germany & A & - & [30] \\
\hline Germany & $A, B, D$ & - & - \\
\hline Italy & - & $\mathrm{B}, \mathrm{C}$ & [31] \\
\hline Romania & - & BIII, BIV, D, E & Present study \\
\hline
\end{tabular}

The presence of $\mathrm{C}$ and $\mathrm{D}$ assemblages typical for canids, and $\mathrm{E}$ from hoofed livestock, in chinchillas is quite interesting. In this work, the existence of assemblages $\mathrm{E}$ in farms BG and RG can be explained by acquiring animals from farms in which ruminants were also kept, the direct or indirect contact between the two species being possible.

Generally, multiple factors can explain the diversity of assemblages identified across the world. Interspecies transmission is of particular importance for the zoonotic risk of infection, domestic animals being the source of human infection. Reverse or cross-species transmission of different assemblages (BIV, E) has also been demonstrated in areas where humans, primates and livestock overlap in their use of habitat [33]. Interspecific transmission is possible between species belonging to different taxa, from rodents to carnivores and from ruminants to humans [34]. It is also proven that G. duodenalis from the North American beaver (Castor canadensis) may infect Mongolian gerbils (Meriones unguiculatus); in this case, the transmission was carried out between two rodent species [35]. Transmission of Giardia spp. between different species of rodents is also confirmed in other older studies [36]. Nevertheless, Goltz [37] demonstrated that $G$. chinchillae from $C$. lanigera were not infective to laboratory mice, rats and guinea pigs. However, the interspecies transmission may explain the presence of assemblages $\mathrm{D}$ and $\mathrm{E}$ in our study, sustained by the existence of guard dogs and small ruminants in the examined farms.

Transport vectors can also play a significant role in the transmission of giardiasis [38]. It is confirmed that assemblage $\mathrm{E}$ of $\mathrm{G}$. duodenalis is carried by flies, increasing the possibility of repeated infection or cross-transmission between sensitive species, by mechanical transmission [39]. 
As a result, despite of the strong host specificity and narrow host range of assemblage $\mathrm{E}$, which is mostly identified in cloven-hoofed mammals, the involvement of the transport hosts can ensure the transmission of this assemblage to captive chinchillas [8].

Water source is also important in the circulation of $G$. duodenalis cysts, giardiasis being recognized as one of the major waterborne diseases [40]. Although the longtailed chinchilla is a species adapted to aridity, with low water needs, it prefers the open dish drinker [41]. The best water supply in chinchilla farming is represented by bottled water, free of pathogens and chlorine [42]. Tap and well water are also accepted sources, but they present the risk of contamination with Giardia cysts. Surprisingly, in Romania, bottled water seems to have an increased risk of infection compared with wells or tap water [43]. Feces of different animal species can pollute water sources, shedding cysts into the water supply [44]. These cysts can pass through water treatment, even for pristine or filtered drinking water. Furthermore, Giardia spp. cysts have a demonstrated effective resistance to chlorination [45]. Tap water was the source in studied farms, without an additional water filtration; chlorination and filtration performed by water plant suppliers being the unique treatments. Combining predisposing factors as interspecific transmission, the possible involvement of vectors and deficiencies in water supply, the increased prevalence of $G$. duodenalis infection in farmed chinchilla from Romania may be explained.

\section{Conclusions}

This study revealed the increased prevalence of infection with G. duodenalis in farmed chinchilla from Romania and the presence of BIII, BIV, D and E assemblages. Further studies are needed to clarify the zoonotic risk for the owners and workers in chinchilla husbandry.

\section{Abbreviations}

BM: Baia Mare; LU: Luncani; RG: Reghin; SB: Suceava-Bejenaru; SM: SuceavaMorozan

\section{Acknowledgements}

The work of VM and AG was carried out under the frame of the USAMV Cluj-Napoca Internal Grant number 6270/2017.

\section{Funding}

This work was supported by a grant of the Romanian National Authority for Scientific Research, CNDI-UEFISCDI, project number 110/2012.

\section{Availability of data and materials}

Nucleotide sequence data from this study were submitted to the GenBank database under the accession numbers MG432793-MG432895.

\section{Authors' contributions}

GCM collected the samples, GA and MV made the flotation and microscopic examinations, KZ performed the DNA extraction, PCR, RFLP and sequencing. All authors read and approved the final manuscript.

Ethics approval and consent to participate Not applicable.
Consent for publication

Not applicable.

\section{Competing interests}

The authors declare that they have no competing interests.

\section{Publisher's Note}

Springer Nature remains neutral with regard to jurisdictional claims in published maps and institutional affiliations.

Received: 8 June 2017 Accepted: 16 January 2018

Published online: 07 February 2018

\section{References}

1. Morrison HG, McArthur AG, Gillin FD, Aley SB, Adam RD, Olsen GJ, et al. Genomic minimalism in the early diverging intestinal parasite Giardia lamblia. Science. 2007;317:1921-6.

2. Cavalier-Smith T. The excavate protozoan phyla Metamonada Grassé emend. (Anaeromonadea, Parabasalia, Carpediemonas, Eopharyngia) and Loukozoa emend. (Jakobea, Malawimonas): their evolutionary affinities and new higher taxa. Int J Syst Evol Microbiol. 2003;53:1741-58.

3. Lindmark DG. Energy metabolism of the anaerobic protozoon Giardia lamblia. Mol Biochem Parasitol. 1980;1:1-12.

4. Monis PT, Caccio SM, Thompson RC. Variation in Giardia: towards a taxonomic revision of the genus. Trend Parasitol. 2009;25:93-100.

5. Plutzer J, Ongerth J, Karanis P. Giardia taxonomy, phylogeny and epidemiology: facts and open questions. Int J Hyg Enviro Health. 2010; 213:321-33.

6. Ryan U, Cacciò SM. Zoonotic potential of Giardia. Int J Parasitol. 2013;43: 943-56.

7. Monis PT, Andrews RH, Mayrhofer G, Ey PL. Genetic diversity within the morphological species Giardia intestinalis and its relationship to host origin. Infect Gen Evol. 2003;3:29-38.

8. Feng Y, Xiao L. Zoonotic potential and molecular epidemiology of Giardia species and giardiasis. Clin Microbiol Rev. 2011;24:110-40.

9. Mircean V, Györke A, Jarca A, Cozma V. Prevalence of Giardia species in stool samples by ELISA in household cats from Romania and risk factors. J Fel Med Sur. 2011;13:479-82

10. Mircean V, Györke A, Cozma V. Prevalence and risk factors of Giardia duodenalis in dogs from Romania. Vet Parasitol. 2012;184:325-9.

11. Onac D, Oltean M, Mircean V, Jarca A, Cozma V. Occurrence of Giardia duodenalis zoonotic assemblages in red foxes from Romania. Sci Parasitol. 2015;16:177-80.

12. Sommer MF, Beck R, lonita M, Stefanovska J, Vasić A, Zdravković N, et al. Multilocus sequence typing of canine Giardia duodenalis from south eastern European countries. Parasitol Res. 2015;114:2165-74.

13. Györke A, Kalmar Z, Dumitrache OM, Gherman MC, Mircean V. Giardia duodenalis genotypes in domestic and wild animals from Romania identified by PCR-RFLP targeting the gdh gene. Vet Parasitol. 2016;217:71-5.

14. Spotorno A, Patton JL. Superfamily Chinchilloidea. In: Patton JL, Pardiňas UFJ, D'Elia G, editors. Mammals of South America. Rodents. Chicago: University of Chicago Press; 2015, pp. 762-786.

15. Anthony HM. Oldest chinchilla rancher visits chinchilla capital. Madera Daily Tribune. 1967;76:12.

16. Soares RM, de Souza SL, Silveira LH, Funada MR, Richtzenhain LJ, Gennari SM. Genotyping of potentially zoonotic Giardia duodenalis from exotic and wild animals kept in captivity in Brazil. Vet Parasitol. 2011;180:344-8.

17. Willis HH. A simple levitation method for the detection of hookworm ova. Med J Aust. 1921:2:375-6.

18. Read CM, Monis PT, Thompson RC. Discrimination of all genotypes of Giardia duodenalis at the glutamate dehydrogenase locus using PCR-RFLP. Infect Genet Evol. 2004;4:125-30.

19. Gillhuber J, Pallant L, Ash A, Thompson RC, Pfister K, Scheuerle MC. Molecular identification of zoonotic and livestock-specific Giardia-species in faecal samples of calves in southern Germany. Parasit Vectors. 2013;6:346.

20. Dryden MW, Payne PA, Ridley R, Smith V. Comparison of common fecal flotation techniques for the recovery of parasite eggs and oocysts. Vet Ther. 2005;6:15-28.

21. Bouzid M, Halai K, Jeffreys D, Hunter PR. The prevalence of Giardia infection in dogs and cats, a systematic review and meta-analysis of prevalence studies from stool samples. Vet Parasitol. 2015;207:181-202. 
22. Oates SC, Miller MA, Hardin D, Conrad PA, Melli A, Jessup DA, et al. Prevalence, environmental loading, and molecular characterization of Cryptosporidium and Giardia isolates from domestic and wild animals along the Central California coast. Appl Environ Microbiol. 2012;78:8762-72.

23. Warburton AR, Jones PH, Bruce J. Zoonotic transmission of giardiasis: a case control study. Commun Dis Rep CDR Rev. 1994:4:R32-6.

24. Levecke B, Meulemans L, Dalemans T, Casaert S, Claerebout E, Geurden T. Mixed Giardia duodenalis assemblage a, B, C and E infections in pet chinchillas (Chinchilla lanigera) in Flanders (Belgium). Vet Parasitol. 2011; 177:166-70.

25. Fehr M. Chinchilla. In: Fehr M, Sassenburg L, Zwart P, editors. Krankheiten der Heimtiere. 6th ed. Hannover: Schluetersche; 2005. p. 183-213.

26. Neringer R, Andersson Y, Eitrem R. A water-borne outbreak of giardiasis in Sweden. Scand J Infect Dis. 1987;19:85-90.

27. Sudré AP. Carvalho Machado do Couto M, Bergamo do Bomfim TC. Occurrence of Giardia intestinalis in dairy goats and evaluation of risk factors for infection: research note. R Bras Ci Vet. 2012;19:149-53.

28. Fialho CG, Oliveira RG, Teixeira MC, Marques SMT, Oliveira RG, Oliveira RG, et al. Comparison of protozoan infection between chinchillas (Chinchilla lanigera) from a commercial breeding facility in southern Brazil and chinchillas from a natural reserve in Chile. Parasitol Latinoam. 2008;63:85-7.

29. Sivkova TN. Parasites of wild and domestic chinchilla. In: Proceedings of the Scientific Conference of the All-Russian Society of Helminthologists RAS "Theory and practice of struggle against parasitic diseases"; 2016, pp. 433-4.

30. Karanis P, Ey PL. Characterization of axenic isolates of Giardia intestinalis established from humans and animals in Germany. Parasitol Res. 1998; 84:442-9.

31. Veronesi F, Piergili Fioretti D, Morganti G, Bietta A, Moretta I, Moretti A, Traversa D. Occurrence of Giardia duodenalis infection in chinchillas (Chincilla lanigera) from Italian breeding facilities. Res Vet Sci. 2012;93:807-10.

32. Pantchev N, Broglia A, Paoletti B, Globokar Vrhovec M, Bertram A, et al. Occurrence and molecular typing of Giardia isolates in pet rabbits, chinchillas, guinea pigs and ferrets collected in Europe during 2006-2012. Vet Record. 2014;175:18.

33. Johnston AR, Gillespie TR, Rwego IB, McLachlan TL, Kent AD, Goldberg TL. Molecular epidemiology of cross-species Giardia duodenalis transmission in western Uganda. PLoS Negl Trop Dis. 2010;4:e683.

34. Davies RB, Hibler CP. Animal reservoirs and cross-species transmission of Giardia. In: Jakubowski W, Hoff JC, editors. Proceedings of a Symposium on Waterborne Transmission of Giardiasis, EPA-600/9-79-001. Cincinnati; 1978. p. 104-27.

35. Faubert GM, Belosevic M, Walker TS, MacLean JD, Meerovitch E. Comparative studies on the pattern of infection with Giardia spp. in Mongolian gerbils. J Parasitol. 1983;69:802-5.

36. Grant DR, Woo PTK. Comparative studies of Giardia spp. in small mammals in southern Ontario. II. Host specificity and infectivity of stored cysts. Can J Zoo. 1978:56:1360-6.

37. Goltz JP. Giardiasis in chinchillas, MSc thesis. Guelph, Ontario, Canada: University of Guelph; 1980.

38. Doiz O, Clavel A, Morales S, Varea M, Castillo FJ, Rubio C, et al. House fly (Musca domestica) as a transport vector of Giardia lamblia. Folia Parasitol (Praha). 2000;47:330-1.

39. Zhao Z, Dong H, Wang R, Zhao W, Chen G, Li S, et al. Genotyping and subtyping Cryptosporidium parvum and Giardia duodenalis carried by flies on dairy farms in Henan, China. Parasit Vectors. 2014;7:190.

40. Karanis $P$, Kourenti $C$, Smith $\mathrm{H}$. Waterborne transmission of protozoan parasites: a worldwide review of outbreaks and lessons learnt. J Water Health. 2007:5:1-38.

41. Hagen K, Clauss M, Hatt JM. Drinking preferences in chinchillas (Chinchilla laniger), degus (Octodon degu) and guinea pigs (Cavia porcellus). J Anim Physiol Anim Nut. 2014;98:942-7.

42. Tapscott B. Standard guidelines for the operation of chinchilla ranches. 1998. http://www.omafra.gov.on.ca/english/livestock/alternat/facts/chinguid. htm. Accessed 15 Sep 2017.

43. Jarcă AD. Epidemiological, clinical, laboratory and therapeutic researches in humans and animals giardiasis. PhD Thesis, University of Medicine and Pharmacy "luliu Hatieganu", Cluj-Napoca, Romania; 2011.

44. Lippy E. Water supply problems associated with a waterborne outbreak of giardiasis. In: Jakubowski W, Hoff JC. Proceedings of a Symposium on Waterborne Transmission of Giardiasis, EPA-600/9-79-001. Cincinnati; 1978 p. $164-74$.
45. Steiner TS, Thielman NM, Guerrant RL. Protozoal agents: what are the dangers for the public water supply? Annu Rev Med. 1997;48:329-40.

46. Martino PE, Bautista EL, Gimeno EJ, Stanchi NO, Radman NE. Fourteen-year status report of fatal illnesses in captive chinchilla (Chinchilla lanigera). J Appl Anim Res. 2016:45:310-4

47. Fagundes Gurgel AC, Dos Santos SA, Pacheco De Araújo FA. Protozoan parasites in captive chinchillas (Chinchilla lanigera) raised in the state of Rio Grande do Sul, Brazil. Parasitol Latinoam. 2005;60:186-8.

48. Petroneto BS, Calegari BF, Sansão P, Bonadiman DC, Moulin GN, Silva MA, et al. Intestinal protozoan in chinchillas (Chinchilla lanigera) created in captivity, the region serrana of state of Espirito Santo, Brasil. Acta Vet Bras. 2015;9:6570

49. Alves JG, Silva AS, Monteiro SG. First report of Cryptosporidium sp. in Chinchilla lanigera in Brazil. Rev FZVA. 2008;15:186-90.

50. Lv C, Wang H, Qi M, Zhang L. Survey of intestinal parasites in pet Chinchilla lanigera. Chin Anim Husb Vet Med. 2009;36:176-7.

51. Qi M, Yu F, Li S, Wang H, Luo N, Huang J, et al. Multilocus genotyping of potentially zoonotic Giardia duodenalis in pet chinchillas (Chinchilla lanigera) in China. Vet Parasitol. 2015;208:113-7.

52. Teixeira RSD. Survey of gastrointestinal parasites in two groups of Chinchilla lanigera in northern Portugal. Dissertação de Mestrado. Universidade de Lisboa, Faculdade de Medicina Veterinária, Lisboa, Portugal; 2013.

53. Kurnosova OP. Specific structure and features of distribution of intestinal protozoa at pets in Moscow. Ros Parazitol Zh. 2013;1:9-15.

54. Souza SLP. Caracterização genética de isolados de Giardia spp. provenientes de amostras fecais de origem humana e animal. Tese de Doutorado, Faculdade de Medicina Veterinária e Zootecnia, Universidade de São Paulo, São Paulo, Brazil; 2007.

55. Cacciò SM, Beck R, Almeida A, Bajer A, Pozio E. Identification of Giardia species and Giardia duodenalis assemblages by sequence analysis of the 5.8S rDNA gene and internal transcribed spacers. Parasitology. 2010;137:919-25.

56. Šedinová J, Flegr J, Ey PL, Kulda J. Use of random amplified polymorphic DNA (RAPD) analysis for the identification of Giardia intestinalis subtypes and phylogenetic tree construction. J Eukaryot Microbiol. 2003;50:198-203.

\section{Submit your next manuscript to BioMed Central and we will help you at every step:}

- We accept pre-submission inquiries

- Our selector tool helps you to find the most relevant journal

- We provide round the clock customer support

- Convenient online submission

- Thorough peer review

- Inclusion in PubMed and all major indexing services

- Maximum visibility for your research

Submit your manuscript at www.biomedcentral.com/submit 